\title{
Workshop Manajemen Stres pada Perawat Pelayanan Kesehatan di Masa Pandemi Covid-19 di Indonesia
}

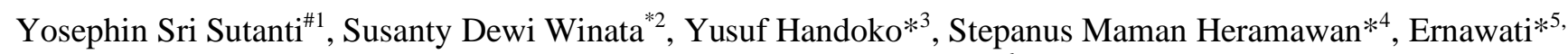 \\ Mey Lona Verawaty Zendrato*6 \\ Departemen Ilmu Kedokteran Kerja Fakultas Kedokteran\&Ilmu Kesehatan, Universitas Kristen Krida Wacana \\ $1,2,3$, \\ Program Studi Diploma III Keperawatan Fakultas Kedokteran\&Ilmu Kesehatan, Universitas Kristen Krida \\ Wacana $^{4,5,6}$ \\ Email: yosephin.sri@ukrida.ac.id; stepanus.hermawan@ukrida.ac.id
}

\begin{abstract}
Abstrak-Konsep sehat menurut World Health Organization (WHO) adalah keadaan yang sempurna baik fisik, mental maupun sosial, tidak hanya sekedar terbebas dari penyakit atau kelemahan/cacat. Namun demikian, pada kenyataannya, para tenaga kesehatan, khususnya perawat, belum dapat dipenuhi perlindungan kesehatan dan keselamatan kerjanya dari berbagai pajanan, khususnya psikososial, apalagi di masa pandemi Covid 19 seperti ini. Tujuan Workshop Manajemen Stres ini adalah untuk mengatasi stres pada perawat yang bekerja di pelayanan kesehatan, yang harus sehat jiwa dan raganya, terutama pada saat pandemi Covid-19. Kegiatan yang diinisiasi oleh LPPM Ukrida ini mendapat dukungan dari PPNI (Perhimpunan Perawat Nasional Indonesia), PERDOKI (Perhimpunan Dokter Spesialis Okupasi Indonesia) dan GPP (Gerakan Pembumian Pancasila). Metode dilakukan secara online memakai zoom cloud meeting dan diikuti oleh 100 orang peserta perawat dari berbagai pusat layanan kesehatan di Indonesia. Kegiatan dibagi menjadi tiga sesi, yaitu sesi pertama paparan dari narasumber yaitu paparan tentang kondisi perawat di Indonesia dan paparan tentang manajemen stres. Pada sesi kedua peserta dibagi dalam kelompokkelompok kecil, untuk melatih diri dalam manajemen stres, dengan didampingi oleh instruktur. Pada sesi ketiga, perawat berkumpul lagi dalam pleno untuk diskusi dan evaluasi. Hasil evaluasi menunjukkan seluruh peserta memberikan nilai "Baik" dan "Baik Sekali"; kecuali satu orang yang memberikan nilai "Cukup" dan tidak ada yang memberikan nilai "Kurang". Para peserta sangat berharap kegiatan serupa dapat diadakan lagi dan sebaiknya diadakan pada hari libur seperti hari Minggu. Kendala utama tidak hadirnya para perawat adalah waktu bekerja yang bertepatan dengan kegiatan

ini.
\end{abstract}

Kata kunci-Covid-19, manajemen, pandemi, perawat, stress
Abstract-The concept of health according to the World Health Organization (WHO) is a state of complete physical, mental and social well-being and free from disease or infirmity or disability. However, the reality is that health workers, especially nurses, have not been able to fulfill their health and safety protection from various exposures, especially psychosocial, especially during the Covid-19 pandemic. The purpose of the Stress Management Workshop is to overcome stress on nurses who work in health services, they must be physically and mentally healthy, especially during the Covid19 pandemic. This activity was initiated by research and community service institutions at Universitas Kristen Krida Wacana and received support from the Indonesian National Nurses Association (INNA), the Association of Indonesian Occupational Specialists and the Pancasila Earthing Movement. The method is carried out online using a zoom cloud meeting with 100 nurses from various health care centers in Indonesia. The activity is divided into several sessions, the first is the presentation from the resource person about the condition of nurses in Indonesia and stress management. The second session was divided into small groups, to train themselves in stress management accompanied by an instructor. The third session in which nurses gathered again in plenary for discussion and evaluation. The results of the evaluation showed that all participants gave "Good" and "Excellent" scores; except for one person who rated "Enough". The participants hope that similar events could be held back and on holidays. The main obstacle is the absence of the nurse working time to coincide with this event.

Keywords_Covid-19, management, nurses, pandemic, stress

\section{PENDAHULUAN}

\subsection{Analisis Situasi}

Kesehatan dan keselamatan kerja (K3) merupakan instrumen yang memproteksi pekerja, perusahaan, lingkungan hidup, dan masyarakat sekitar dari bahaya 
akibat kecelakaan kerja ${ }^{(1)}$. Perlindungan tersebut merupakan hak asasi pekerja yang wajib dipenuhi oleh individu maupun organisasi bertujuan mencegah, mengurangi, bahkan menihilkan risiko kecelakaan kerja (zero accident). K3 menjadi semakin penting karena berdampak pada produktivitas dan kualitas kehidupan kerja $^{(2)}$.

Sesuai dengan amanah Undang-Undang No. 36 tahun 2009 tentang kesehatan dan secara khusus pada Bab XII mengenai Kesehatan Kerja menyatakan bahwa kesehatan kerja memiliki tujuan untuk menjaga pekerja dapat hidup sehat dan terbebas dari gangguan kesehatan serta pengaruh buruk yang diakibatkan pekerjaan ${ }^{(3)}$. Keselamatan kerja atau Occupational Safety, dalam istilah sehari hari sering disebut dengan safety saja, secara filosofi diartikan sebagai suatu pemikiran dan upaya untuk menjamin keutuhan dan kesempurnaan baik jasmaniah maupun rohaniah tenaga kerja pada khususnya dan manusia pada umumnya serta hasil budaya dan karyanya ${ }^{(4)}$.

Bahaya potensial dalam bekerja dilihat dalam berbagai pajanan, yaitu pajanan fisika, kimia, biologis, ergonomis, dan psikologis ${ }^{(5)}$. Pajanan fisika mencakup suhu yang panas, ventilasi yang kurang, penerangan/cahaya yang kurang. Pajanan kimia berasal dari asap tungku dan uap minyak goreng. Sedangkan pajanan biologis berupa mikroorganisme yang paling kecil seperti virus, bakteri, jamur, parasit, dan debu organik. Sementara pajanan ergonomis tampak dari buruknya adaptasi terhadap sistem, alat, prosedur kerja (fitting the job and tool to the man); sedangkan pajanan psikologis terkait dengan stres kerja, kelelahan kerja, demotivasi, dan bekerja seadanya ${ }^{(6)}$. Hal tersebut terjadi sebagai ketidakseimbangan antara tuntutan okupasional (pekerjaan) dan kapabilitas (pengetahuan, keterampilan, dan kemampuan) kerja individu.

Sejak awal bulan Maret 2020 telah dinyatakan bahwa Indonesia juga mengalami pandemi Covid 19, yang sampai saat ini belum mampu diatasi, bahkan banyak tenaga medis berguguran ${ }^{(7)}$. Dalam masa pandemi ini terlihat bagaimana para tenaga kesehatan, khususnya perawat sempat "angkat tangan" dengan memuat di media sosial dengan "Indonesia Terserah", karena secara psikologis merasa sudah tak kuat lagi.

Perawat adalah tenaga kesehatan yang berperan besar dalam pelayanan kesehatan di Indonesia, khususnya dalam pelayanan kesehatan di masa pandemi
Covid-19(8). Oleh karenanya, diperlukan observasi pendahuluan untuk memahami pentingnya tata kelola kesehatan dan keselamatan kerja dalam mengatasi pajanan (bahaya) potensial. Untuk mempermudah pemahaman tentang K3, dapat digunakan konsep umum dari cara berpikir rasional yang biasa digunakan. Mengadopsi istilah $5 \mathrm{~W}+1 \mathrm{H}$ dapat mempermudah setiap orang berpikir secara sistematis, di dalam memahami dan menerapkan prinsip-prinsip K3. Selain pendekatan di atas, juga perlu peta pemahaman dasar dengan cara melakukan analisis "SWOT"((9).

Analisis SWOT adalah sebuah bentuk analisa situasi dan kondisi yang bersifat deskriptif (memberi suatu gambaran). Analisa ini menempatkan situasi dan kondisi sebagai faktor masukan, lalu kemudian dikelompokkan menurut kontribusinya masing-masing, yang ditujukan untuk menggambarkan situasi yang sedang dihadapi, dan bukan sebuah alat analisis yang mampu memberikan jalan keluar bagi permasalahan kesehatan dan keselamatan kerja yang sedang dihadapi.

Analisis SWOT (Strengths, Weaknesses, Opportunities, dan Threats) telah menjadi salah satu alat yang berguna dalam dunia industry ${ }^{(10)}$. Proses penggunaan manajemen analisis SWOT menghendaki adanya suatu survei internal tentang strengths (kekuatan) dan weaknesses (kelemahan), serta survei eksternal atas opportunities (kesempatan/ peluang) dan threats (ancaman) ${ }^{(11)}$.

Secara umum, muncul sejumlah pertanyaan untuk membantu memahami peta SWOT dari para perawat dan lingkungan kerjanya. Pertanyaan-pertanyaan yang diajukan, diantaranya bagi perawat sebagai subyek dampingan adalah: 1) kekuatan dan kelemahan apa saja yang dimiliki perawat?; 2) peluang dan ancaman apa yang dipunyai perawat? Analisis SWOT sebagai pendekatan strategis dalam tata kelola kesehatan dan keselamatan kerja untuk mengatasi berbagai pajanan (bahaya) potensial bagi para perawat menjadi penting dan mendesak, terutama bila dikaitkan dengan perlunya upaya peningkatan kesejahteraan psikologis (wellbeing), kesejahteraan finansial, dan kesejahteraan ergonomis.

Tabel I berikut ini menyajikan analisis kekuatan, kelemahan, peluang dan ancaman mengenai situasi dan kondisi K3 dan psikologi kesehatan kerja para perawat di Indonesia. 
Tabel I. Analisis Kekuatan, Kelemahan, Peluang, dan Ancaman

\begin{tabular}{|c|c|c|c|c|}
\hline No & $\begin{array}{l}\text { Analisis } \\
\text { Kekuatan }\end{array}$ & Analisis Kelemahan & $\begin{array}{l}\text { Analisis } \\
\text { Peluang }\end{array}$ & Analisis Ancaman dan Tantangan \\
\hline 1 & $\begin{array}{lr}\text { Jumlah } & \text { perawat } \\
\text { relatif } & \text { cukup } \\
\text { banyak. } & \end{array}$ & $\begin{array}{l}\text { Lamanya bekerja dan } \\
\text { waktu bekerja yang } \\
\text { kebanyakan melawan irama } \\
\text { sirkadian, terutama } \\
\text { dikaitkan dengan } \\
\text { kesehatan, keamanan, dan } \\
\text { keselamatan kerja (bekerja } \\
\text { dalam durasi lama dengan } \\
\text { shift } \text { kerja) }\end{array}$ & $\begin{array}{l}\text { Meningkatnya perhatian } \\
\text { pemerintah nasional dan } \\
\text { daerah terhadap K3 } \\
\text { perawat }\end{array}$ & $\begin{array}{l}\text { Potensial masuknya tenaga kesehatan } \\
\text { asing ke Indonesia, dengan upah kerja } \\
\text { yang lebih murah }\end{array}$ \\
\hline 2 & $\begin{array}{l}\text { Perawat tersebar di } \\
\text { seluruh Indonesia }\end{array}$ & $\begin{array}{l}\text { Kualitas sarana, prasarana } \\
\text { dan dukungan psikologis di } \\
\text { tiap daerah berbeda-beda }\end{array}$ & $\begin{array}{l}\text { Dukungan pemerintah } \\
\text { dan masyarakat/ormas } \\
\text { cukup besar, namun } \\
\text { dukungan psikologis } \\
\text { belum ada }\end{array}$ & $\begin{array}{l}\text { Luasnya daerah dan makin } \\
\text { meningkatnya jumlah positif }\end{array}$ \\
\hline
\end{tabular}

Sumber: Hasil Observasi Tim Gugus Kemanusiaan GPP (Gerakan Pembumian Pancasila) membantu Alat Pelindung Diri (APD) selama Pandemi, Maret-Juli 2020

Melihat masalah di atas, maka diambil rencana dukungan psikologis berupa tatalaksana untuk mengatasi stres pada perawat yang bertugas sebagai petugas kesehatan di pelayanan kesehatan dalam masa pandemi ini.

Secara umum tujuan pengabdian ini adalah :

1. Untuk memahami pentingnya kesehatan dan keselamatan kerja dengan mengedepankan prinsipprinsip kerja yang safety

2. Meningkatkan pengetahuan, keterampilan, sikap kerja yang sehat, aman, dan nyaman dalam bekerja

3. Menyadarkan dan meningkatkan kesadaran subyek dampingan untuk bersedia berubah dalam penatalaksanaan stres akibat kerja

\subsection{Permasalahan Mitra}

Berdasarkan hasil observasi pendahuluan, perawat sebagai petugas depan pelayanan kesehatan berada dalam situasi dan kondisi kerja yang tidak sehat dan beresiko pada keselamatan kerja, khususnya pajanan psikologis akibat Covid 19. Petugas kesehatan khususnya perawat menjadi subyek dampingan mitra Gerakan Pembumian Pancasila (GPP), yang sejak awal pandemi mendapatkan bantuan APD melalui jejaring GPP, tetapi belum pernah dibuat pendampingan psikologis.

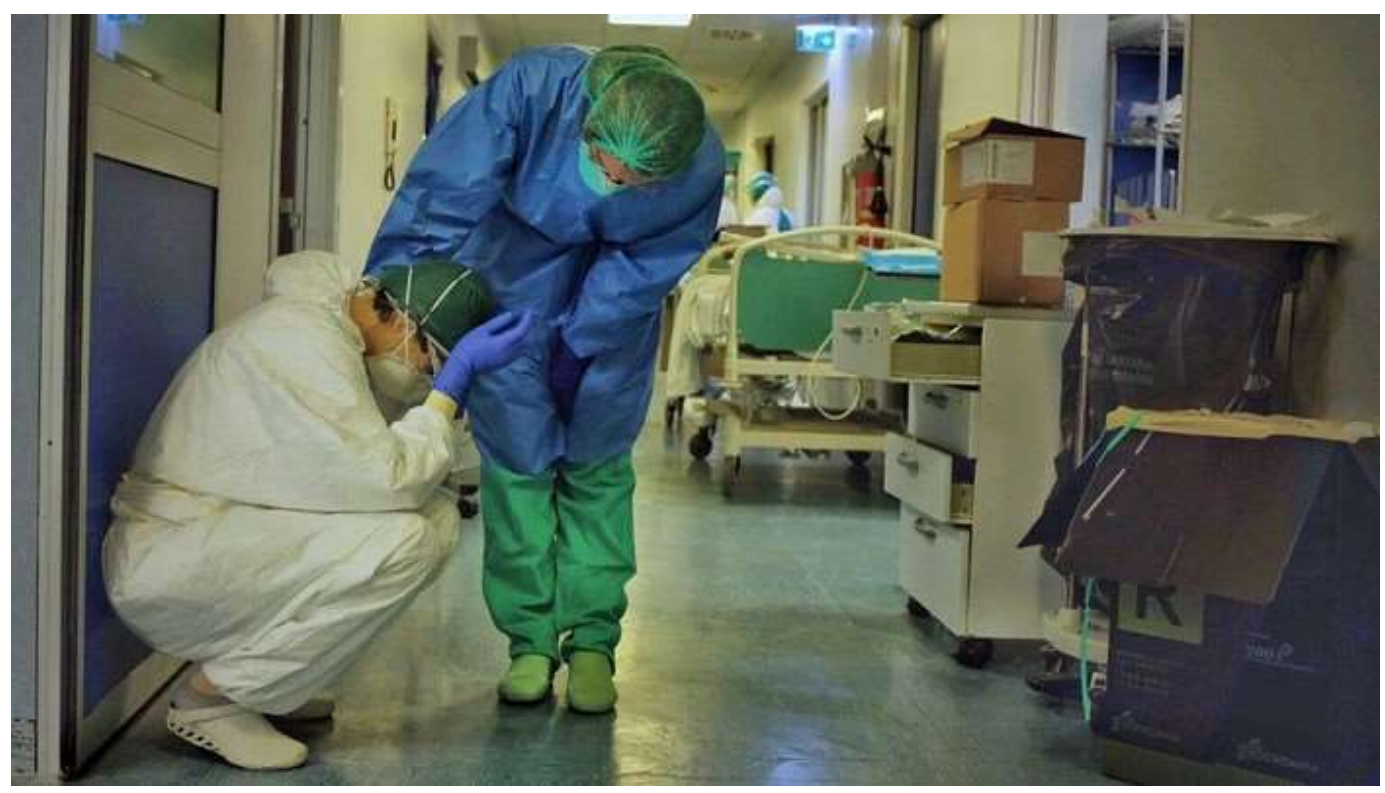




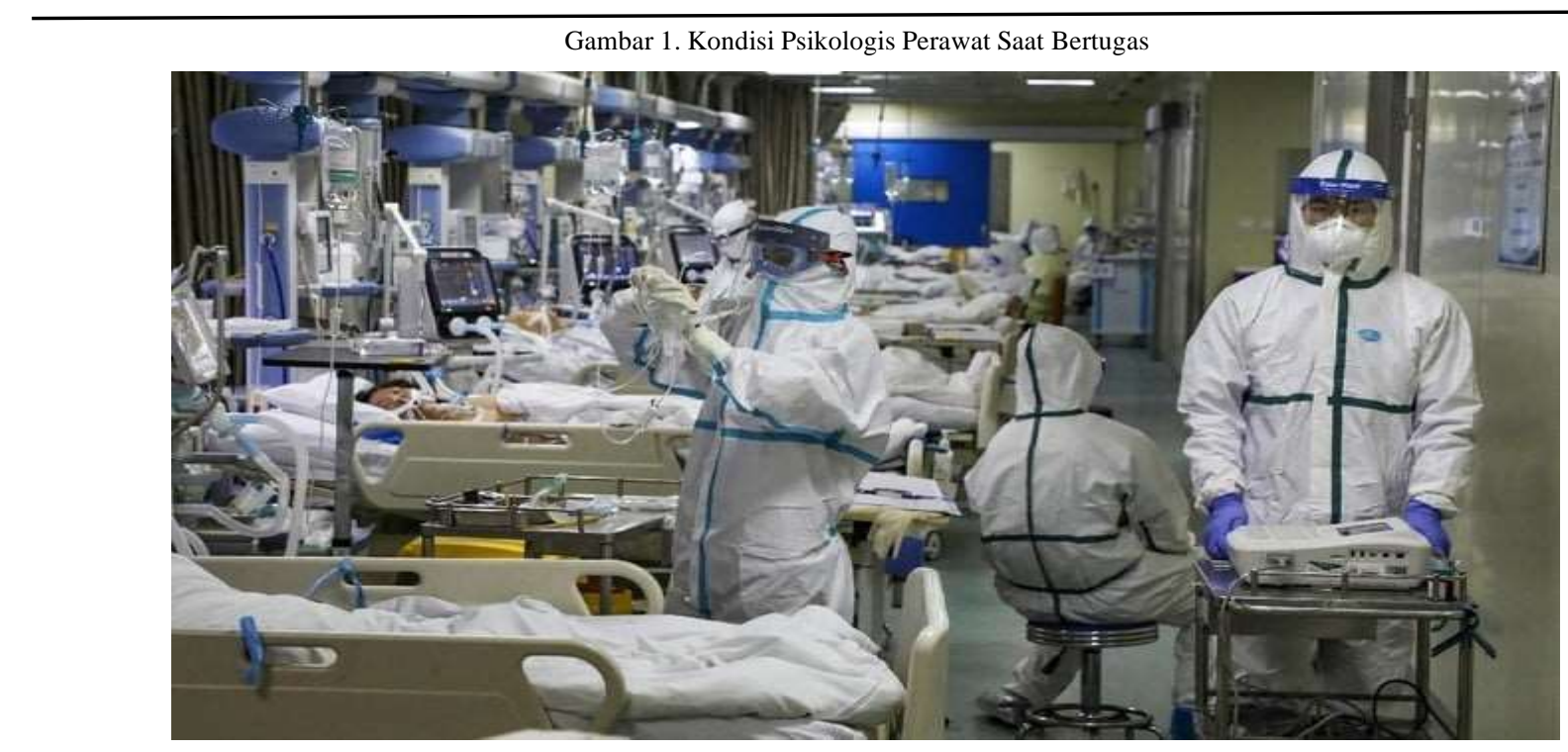

Gambar 2. Suasana Ruangan Kerja Perawat di Pelayanan Kesehatan

\section{SOLUSI}

2.1. Solusi

Solusi yang akan diberikan dalam kegiatan pendampingan ini adalah:

1. Sebelum dilakukan penatalaksanaan atas pajanan yang dialami para perawat, tim pendamping/pengusul terlebih dahulu melakukan identifikasi secara menyeluruh dan mendalam terhadap pajanan yang ada bagi subyek dampingan dan lingkungan kerjanya.

2. Hasil identifikasi yang dilakukan oleh tim akan sangat membantu dalam menyusun program penatalaksanaan dan pendampingan kesehatan dan keselamatan kerja bagi para perawat dan lingkungan kerjanya.

3. Hasil temuan menjadi dasar pengembangan pemahaman teoritis tentang 5 (lima) pajanan/ bahaya potensial dari perawat akibat kompleksitas permasalahan yang dihadapi pekerja, khususnya pajanan psikososial.

4. Bersama-sama dengan para perawat merumuskan prioritas intervensi masalah, khususnya masalah psikologis.

5. Membantu mitra dalam mengembangkan lingkungan kerja yang sehat dan ergonomis.

Dalam mengatasi berbagai pajanan/ bahaya potensial yang ada, besar kemungkinan para perawat mengalami hambatan dan kendala. Oleh karenanya, diperlukan upaya sistematis mengambil langkah-langkah terencana untuk mengurangi hambatan dan kendala dimaksud.

2.2. Sosialisasi Hasil temuan

Salah satu cara untuk sosialisasi hasil adalah dengan membuat kegiatan secara daring. Bentuk yang dipilih berupa webinar yang dilanjutkan workshop bagi perawat yang bekerja di layanan kesehatan.

Luaran yang diharapkan dalam kegiatan pendampingan ini adalah:

1. Meningkatkan kesadaran kepada perawat mengenai pajanan/ bahaya-bahaya potensial yang berhubungan dengan pekerjaan sebagai pengrajin keripik.

2. Menyusun prosedur-prosedur kerja yang sehat, aman, dan nyaman serta mengembangkan lingkungan kerja yang higienis pada area kerja subyek pendampingan

\section{METODE PELAKSANAAN}

Kegiatan ini dilakukan dengan kolaborasi bersama Perhimpunan Spesialis Kedokteran Okupasi Indonesia (PERDOKI) dan Gerakan Pembumian Pancasila (GPP), didukung Perdoki (Perhimpunan Spesialis Kedokteran Okupasi Indonesia) dan PPNI (Perhimpunan Perawat Nasional Indonesia), sebagai bentuk dukungan bidang psikososial kepada perawat di masa pandemi.

\subsection{Proses sebelum kegiatan}

Identifikasi pajanan serta penatalaksanaan manajemen stres bagi perawat sebagai subyek dampingan dimaksudkan untuk membekali para perawat agar kualitas kesehatan, kesejahteraan psikologis, dan lingkungan kerja ergonomisnya meningkat sehingga dapat dan lebih berfungsi optimal dalam menghadapi berbagai permasalahan yang muncul dalam proses kerja. Untuk itu, dipaparkan kerangka pemecahan masalah untuk memberikan acuan bagi semua pihak yang berkepentingan dalam kegiatan ini.

1. Mengidentifikasi pajanan/ bahaya potensial

2. Merumuskan masalah yang ditimbulkan oleh pajanan. 

3. Menyusun solusi alternatif kreatif berdasarkan skala prioritas
4. Mengeksekusi pemecahan masalah
5. Monitoring dan evaluasi program
6. Memberikan umpan balik

\subsection{Kepanitiaan}

Kegiatan diadakan melalui media online (zoom meeting clouds), dengan host atau penanggung jawab media adalah Prodi Keperawatan FKIK UKRIDA. Susunan panitia sebagai berikut:

Ketua Tim: dr. Susanty Dewi Winata, MKK (Ukrida)

Sekretaris: Ernawati, SKp., MNg (Ukrida)

Bendahara: dr. Yusuf Handoko, MKK, SpOk (Ukrida)

Anggota: dr Endang Jojor, SpOk (Perdoki DKI Jakarta), Ns. Stepanus Maman Hermawan, M.Kep (Ukrida), dr Erdy Techrisna, MKK, MARS (GPP/Ukrida), dr Yuliana (GPP)

Narasumber: Dr. dr. Yosephin Sri Sutanti, MS., SpOk (Ukrida) dan Ns. Mey Lona Verawaty Zendrato, M.Kep (Ukrida)

Instruktur: Tim Instruktur Perdoki dan Ukrida
Rapat diadakan setiap minggu sekali untuk memastikan persiapan narasumber, susunan acara dan evaluasi, serta pengajuan SKP PPNI. Setelah semua siap, segera dibuat flyer dan surat undangan beserta TOR (Term of Reference) kegiatan. Selain itu juga diadakan pertemuan para instruktur untuk menyamakan persepsi pelatihan.

3.3. Persiapan Metode yang Digunakan

1. Identifikasi stres menggunakan metode kuesioner Perceive Stress Scale sebelum kegiatan dilakukan, untuk data dasar melihat kondisi peserta perawat $^{(12)}$.

2. Persiapan sarana daring dengan sistem pembagian kelompok kecil (breakoutroom). Proses pendampingan subyek menggunakan metode experential learning (pembelajaran bersama dengan mengalami), dimana subyek dampingan dikenalkan pada ide dan konsep, kemudian terlibat langsung dalam proses, dan diharapkan bisa menerapkan prinsip-prinsip kesehatan dan keselamatan kerja (K3), khususnya manajemen stres, melalui pelatihan atau workshop.

3. Pertemuan bagi para instruktur yang akan menjadi pendamping, supaya persepsi dan langkah kerja pada saat mendampingi kelompok relatif sama.

\section{PROSES PELAKSANAAN}

Tabel II. Susunan Acara

\begin{tabular}{|c|c|c|c|}
\hline Waktu & Kegiatan & Person/ PIC & Keterangan \\
\hline $09.00-09.15$ & Pendaftaran ulang dan Pretest & Tim Kerja Bersama & Pleno \\
\hline \multirow[t]{7}{*}{ 09.15-10.00 } & Pembukaan & $\mathrm{MC}$ & Pleno \\
\hline & "Indonesia Raya" & & \\
\hline & Doa Pembukaan & Ketua Tim Kerja & \\
\hline & Opening Speech & Rektor Ukrida & \\
\hline & Keynote Speaker 1 & Ketua PERDOKI & \\
\hline & Keynote Speaker 1 & Ketua PPNI & \\
\hline & Keynote Speaker 1 & Ketua GPP & \\
\hline $10.00-11.00$ & $\begin{array}{l}\text { Materi 1: } \\
\text { Kondisi Perawat Indonesia di } \\
\text { Masa Pandemi Covid } 19\end{array}$ & Ns. Mey Lona Verawaty Zendrato, M.Kep & Pleno \\
\hline $11.00-12.00$ & $\begin{array}{l}\text { Materi 2: } \\
\text { Manajemen Stres }\end{array}$ & Dr. dr. Yosephin Sri Sutanti, MS., SpOk & Pleno \\
\hline $12.00-13.00$ & ISHOMA & - & - \\
\hline $13.00-15.00$ & $\begin{array}{l}\text { Pelatihan Ke-1 Manajemen } \\
\text { Stres }\end{array}$ & Tim Instruktur & $\begin{array}{l}\text { Breakout Room } \\
\text { (grup kecil) }\end{array}$ \\
\hline $15.00-15.10$ & Relaksasi & Tim Kerja & Pleno \\
\hline $15.10-16.30$ & $\begin{array}{l}\text { Pelatihan Ke-2 } \\
\text { Manajemen Stres }\end{array}$ & Tim Instruktur & $\begin{array}{l}\text { Breakout Room } \\
\text { (grup kecil) }\end{array}$ \\
\hline $16.30-16.45$ & Posttest \& Evaluasi & Tim kerja & Pleno \\
\hline $16.45-17.00$ & Closing Statement & Tim Kerja & Pleno \\
\hline
\end{tabular}




\subsection{Proses Acara}

Rektor Ukrida, Dr.dr. Wani Devita Gunardi, Sp.MK, dalam sambutannya menyatakan sangat bangga LPPM Ukrida bisa mendukung kegiatan yang sangat positif di masa pandemi Covid 19 ini, untuk membantu para perawat mengatasi stres yang dialami. Ke depannya, Ukrida sangat terbuka untuk bersinergi dengan GPP, Perdoki dan PPNI dalam membantu mengatasi pandemi Covid 19 ini. Adapun Dr. dr. Astrid Sulistomo, M.P.H., Sp.Ok sebagai Ketua Perdoki mengatakan bahwa kegiatan seperti ini harus terus didukung, bahkan dapat diperluas untuk pekerja yang lain. Hal ini memang sejalan dengan tugas para dokter spesialis kedokteran okupasi atau kedokteran kerja yang bergerak untuk kesehatan dan keselamatan pekerja, termasuk kesehatan mental pekerja. Dr. Harif Fadhillah, S.Kp.,S.H.,M.Kep.,M.H sebagai Ketua Umum DPP PPNI merasa senang karena kegiatan positif seperti ini menjadi bukti nyata untuk bergandengan tangan menangani pandemi Covid 19 ini, khususnya bagi perawat yang terdampak secara mental. Tingkat stres pada perawat sudah cukup tinggi di masa biasa, apalagi di masa pandemi ini. Ketua Umum DPP GPP Dr. Antonius D.R. Manurung, M.Si memberikan apresiasi dengan terbentuknya Tim Kerja Bersama ini, yang membuktikan pelaksanaan nilai-nilai Pancasila sebagai sesama anak bangsa. Melalui kerja gotong royong seperti inilah diharapkan bangsa Indonesia perlahan-lahan dapat bangkit dari kesulitan di masa pandemi.

Kegiatan ini dihadiri oleh sekitar seratus orang dari berbagai pelosok Indonesia. Namun demikian, pada saat workshop tidak semua bisa turut serta sampai akhir karena sebagian perawat masih bekerja sesuai tuntutan di masa pandemi Covid 19. Workshop Manajemen Stres kali ini memang dikhususkan bagi perawat yang bekerja di pelayanan kesehatan. Peserta yang aktif mengikuti workshop sampai akhir sebanyak 49 orang. Mereka sangat antusias, walaupun beberapa diantara mereka harus tutup video karena sambil bekerja saat kegiatan berlangsung.

Kegiatan dibagi menjadi tiga sesi, yaitu sesi pertama diisi oleh paparan dua narasumber yaitu paparan tentang "Kondisi Perawat Indonesia di silnya sebagai berikut:
Masa Pandemi Covid 19" oleh Ns.Mey Lona Verawaty Zendrato, S.Kep., M.Kep (Kepala Prodi Keperawatan FKIK Ukrida) dan paparan tentang "Manajemen Stres pada Perawat Pelayanan Kesehatan di Masa Pandemi Covid 19" oleh Dr.dr.Yosephin Sri Sutanti, MS., SpOk (Departemen Ilmu Kedokteran Kerja, kekhususan pajanan psikososial). Pada sesi kedua peserta dibagi dalam kelompok-kelompok kecil, untuk melatih diri dalam manajemen stres, dengan didampingi oleh para instruktur Terakhir pada sesi ketiga, para perawat berkumpul lagi dalam pleno untuk diskusi dan evaluasi bersama.

\subsection{Evaluasi}

Pertanyaan evaluasi untuk peserta sebagai berikut:

1. Instruktur memiliki kompetensi dan wawasan di bidang Manajemen Stres

2. Instruktur menguasai materi yang dilatihkan kepada peserta workshop

3. Instruktur menguasai materi yang dilatihkan kepada peserta workshop.

4. Instruktur menggunakan bahan pelatihan (media cetak/ benda nyata/ model simulator/ audio/ video/ multimedia/ presentasi) yang memotivasi peserta

5. Instruktur menggunakan bahan pelatihan (media cetak/ benda nyata/ model simulator/ audio/ video/ multimedia/ presentasi) yang melibatkan peserta

6. Instruktur menggunakan bahan pelatihan (media cetak/ benda nyata/ model simulator/ audio/ video/ multimedia/ presentasi) yang berkualitas baik.

7. Instruktur menyajikan contoh-contoh yang relevan dengan isi atau materi program workshop

8. Instruktur membantu peserta untuk menguasai kompetensi- kompetensi yang dilatihkan

9. Instruktur selalu memberikan umpan balik/ feedback atas tugas yang diberikan.

10. Instruktur mengajukan pertanyaan-pertanyaan tentang isi atau materi workshop kepada peserta.

Tabel III. Hasil Evaluasi

\begin{tabular}{lcccccccccc}
\hline Pertanyaan & 1 & 2 & 3 & 4 & 5 & 6 & 7 & 8 & 9 & 10 \\
\hline Baik Sekali & 28 & 25 & 25 & 20 & 22 & 21 & 21 & 24 & 22 & 20 \\
\hline Baik & 2 & 5 & 5 & 9 & 7 & 9 & 9 & 5 & 7 & 10 \\
\hline Cukup & 0 & 0 & 0 & 1 & 1 & 0 & 0 & 1 & 1 & 0 \\
\hline
\end{tabular}




$\begin{array}{lllllllllll}\text { Kurang } & 0 & 0 & 0 & 0 & 0 & 0 & 0 & 0 & 0 & 0\end{array}$

Hasil evaluasi menunjukkan hampir seluruh peserta memberikan nilai "Baik Sekali" dan "Baik" (67\% -93\% yang menjawab "Baik Sekali”, sisanya "Baik"), hanya satu orang yang memberikan nilai "Cukup" (3\%) dan tidak ada yang memberikan nilai "Kurang".

\subsection{Saran}

Dalam sesi terakhir pleno, para peserta menyatakan bahwa mereka sangat mendapatkan manfaat dari kegiatan ini dan sangat berharap kegiatan serupa dapat diadakan lagi tetapi sebaiknya diadakan pada hari libur seperti hari Minggu. Kendala utama ketidakhadiran para perawat kebanyakan adalah waktu bekerja yang bertepatan dengan kegiatan ini.

\section{KESIMPULAN}

Kegiatan yang diinisiasi oleh LPPM Ukrida dan mendapat dukungan dari PPNI (Perhimpunan Perawat Nasional Indonesia), PERDOKI (Perhimpunan Dokter Spesialis Okupasi Indonesia) dan GPP (Gerakan Pembumian Pancasila) ini telah berlangsung dengan baik. Metode dilakukan secara online memakai zoom cloud meeting dan diikuti oleh 100 orang peserta perawat dari berbagai pusat layanan kesehatan di Indonesia. Hasil evaluasi menunjukkan seluruh peserta memberikan nilai "Baik" dan "Baik Sekali"; kecuali satu orang yang memberikan nilai "Cukup" dan tidak ada yang memberikan nilai "Kurang". Para peserta sangat berharap kegiatan serupa dapat diadakan lagi dan sebaiknya diadakan pada hari libur seperti hari Minggu. Kendala utama tidak hadirnya para perawat adalah waktu bekerja yang bertepatan dengan kegiatan ini.

\section{DAFTAR PUSTAKA}

1. Musab A. Impact of Applying Occupational Safety and Health Programs on Employees Performance in Construction Sector. Solid State Technol. 2020;63(6):3332-46.

2. Yuliandi CD, Ahman E. Penerapan Keselamatan Dan Kesehatan
Kerja (K3) Di Lingkungan Kerja Balai Inseminasi Buatan (Bib) Lembang. Penerapan Keselam Dan Kesehat Kerja Di Lingkung Kerja Balai Inseminasi Buatan Lembang. 2019;18(2):98-109.

3. Jaya B, Hairul A. Implementasi Sistem Manajemen Kesehatan dan Keselamatan Kerja (SMK3) pada Karyawan Di Perusahaan Daerah Air Minum Kabupaten Tapin. J Ilm Ekon Binis Issn Online 2615-2134. 2020;7(1):1-19.

4. Purnomo DH, Indasah I, Melda B. Analysis of Implementation Safety and Health Occupational Management System in Kertosono General Hospital. J Qual Public Heal. 2018;1(2):7885.

5. Rai R, El-Zaemey S, Dorji N, Rai BD, Fritschi L. Exposure to occupational hazards among health care workers in low-and middle-income countries: A scoping review. Int J Environ Res Public Health. 2021;18(5):1-41.

6. Siswati, Diyanah KC. Analisis Risiko Pajanan Debu (Total Suspended Particulate) di Unit Packer PT. X. J Kesehat Lingkung. 2017;9(1):100-10.

7. Suryani NL. Covid 19 And New Normal. Desanta Muliavisitama. 2020. 1-309 p.

8. Kurniati A, Dwi Astari L, Ferry Efendi SKep Ms, Haryanto J, Dianawatisari H, Ifrani Yuan Khaulaha Rani S, et al. Analisis Kebijakan Pemenuhan Pasar Kerja Tenaga Kesehatan di Tingkat Global. 2020th ed. Jakarta: Kementerian Kesehatan Republik Indonesia; 2020.

9. Taufiqur R, Susetyo R. Usulan Penerapan Keselamatan Dan Kesehatan Kerja. J Inov [Internet]. 2014;10(2):96-103. Available from:

https://www.google.com/url?sa=t\&rct=j\&q=\&esrc=s\&source $=\mathrm{w}$ eb\&cd=\&ved=2ahUKEwjR0IeJh4r0AhXLXisKHVCzD2QQFno ECAUQAQ\&url=https $\% 3 \mathrm{~A} \% 2 \mathrm{~F} \% 2$ Fejurnal.esaunggul.ac.id $\% 2$ Findex.php\%2Finovisi\%2Farticle\%2Fdownload\%2F1809\%2F16 29\&usg=AOvVaw1yOAVyP23buj91yNyz0Jcc

10. Benzaghta MA, Elwalda A, Mousa M, Erkan I, Rahman M. SWOT analysis applications: An integrative literature review. J Glob Bus Insights. 2021;6(1):55-73.

11. Fitri Anggreani T. Faktor-Faktor Yang Mempengaruhi Swot: Strategi Pengembangan Sdm, Strategi Bisnis, Dan Strategi Msdm (Suatu Kajian Studi Literatur Manajemen Sumberdaya Manusia). J Ekon Manaj Sist Inf. 2021;2(5):619-29.

12. She Z, Li D, Zhang W, Zhou N, Xi J, Ju K. Three versions of the perceived stress scale: Psychometric evaluation in a nationally representative sample of chinese adults during the covid-19 pandemic. Int J Environ Res Public Health. 2021;18(16):1-9. 